\title{
METHICILLIN RESISTANT Staphylococcus aureus (MRSA) IN CAMEL MEAT: PREVALENCE AND ANTIBIOTIC SUSCEPTIBILITY
}

\author{
Waleed R. El-Ghareeb" ${ }^{1,2, *}$, Faisal S. Almathen ${ }^{1}$, Mahmoud M. Fayez ${ }^{3}$, Raed A. Alsultan ${ }^{4}$
}

${ }^{1}$ Department of Veterinary Public Health and Animal Husbandry, College of Veterinary Medicine and Animal Resources, King Faisal University, 400 Al-Hasa, 31982, Saudi Arabia, ${ }^{2}$ Food Control Department, Faculty of Veterinary Medicine, Zagazig University, 44519, Egypt, ${ }^{3}$ Veterinary Serum and Vaccine Research Institute, Cairo, Egypt, ${ }^{4}$ Ministry of Environment, Water and Agriculture, Saudi Arabia

${ }^{\star}$ Corresponding author, E-mail: welsaid@kfu.edu.sa

\begin{abstract}
This study is an initiative study intended to investigate the prevalence and antibiotic susceptibility of Staphylococcus aureus and MRSA obtained from fresh camel meat retailed in Al-Hasa, Saudi Arabia. The survey has been conducted for five months where fresh camel meat were microbiologically analyzed to isolate $S$. aureus using culture media and VITEK2 technique. The Identification of $S$. aureus was done by DNA expression of gene specific 16S rRNA, while mecA gene expression was recognized in the identified MRSA isolates using PCR. The recorded prevalence of $S$. aureus was $10.7 \%$ $(20 / 187)$ from raw camel meat. Three isolates out of twenty $S$. aureus isolates were confirmed to be MRSA. Susceptibility to 10 antimicrobials was estimated using the disc diffusion method. These results suggested that MRSA is found in camel meat retailed at AlHasa, Saudi Arabia. We recommend that, surveillance protocol should be embraced in meat safety and public health programs.
\end{abstract}

Key words: camel meat, S. aureus, MRSA, antimicrobial resistance

\section{Introduction}

Staphylococcus aureus is an important pathogen causing food-borne illness worldwide and causes serious diseases in human being (1). The main sources of infection could be the inadequate personnel hygiene, unhygienic handling and storage of food infected with staphylococci. Frequently associated foods are meat, dairy products, cream-filled bakery items and salads (2). Methicillin-resistant S. aureus (MRSA) appeared as a dangerous agent for different patients and especially in those with impaired im- mune system. MRSA strains are actually widespread human isolate but are unusual animal isolates (3). MRSA firstly recognized as nosocomial infection. Later in the community and livestock. It has a continuous and dynamic epidemiology. Human may acquire MRSA infection via contact with contaminated environment or contaminated marketed meat $(4,5)$. Resistance in MRSA is mediated by the gene mecA, which located on the chromosome in staphylococcal cassette chromosome mec (SCCmec), and this encodes penicillin-binding protein (PBP) 2a with a low affinity for betalactams (6).Transmission of MRSA from food 
to people causes a serious problem especially for the immunocompromised people. S. aureus was identified in 42 out of 176 raw meat (beef, poultry and pork) over a one-year survey (7) and they did not find any evidence indicating vancomycin, or methicillin-resistance. S. aureus also isolated from the wild animal carcasses (2.0\% prevalence) and authors found no methicillin-resistance (8). Several studies in Saudi Arabia were conducted to investigate the prevalence, risk factors and genetic distribution of MRSA isolated from healthy and clinical human and animal cases (9-14). However, rare reports were recorded with regard to the prevalence of MRSA in food especially camel meat. To the best of our knowledge, few studies were conducted to isolate and identify MRSA from camel meat allover Arabian countries (15, 16).This study was done to investigate the MRSA prevalence in camel meat samples retailed to the public at Al-Hasa, Saudi Arabia. mec-A gene expression was carried out in identified S. aureus isolates using PCR. Antimicrobial resistance profile for the $S$. aureus isolates were further analyzed. This study is one of the very few studies regarding the prevalence and genetic characters of MRSA from camel meat in Saudi Arabia.

\section{Materials and methods}

All experiments followed the ethical and scientific principles adopted by King Faisal University, Saudi Arabia.

\section{Collection of samples}

A total of 187 minced camel meat samples were collected randomly from supermarkets in Al-Hasa province, Saudi Arabia in a 5 months period. The collected samples were taken directly in sterile polyethylene bags (icebox) to the Meat Hygiene laboratory at the Veterinary Public Health and Animal Husbandry Department, College of Veterinary Medicine, King Faisal University for the subsequent microbial culturing and identification.

Isolation and identification of coagulase positive S. aureus

For investigation of coagulase positive $S$. $a u$ reus, after sample digestion in a Stomacher ${ }^{\circledR}$
400 Circulator, an inoculum of $0.1 \mathrm{ml}$ of serial dilution $10^{-1} \& 10^{-2}$ was evenly surface distributed on Baird Parker agar base supported with egg yolk tellurite emulsion Agar (Oxoid CM0275) according to (17). After incubation at $37^{\circ} \mathrm{C}$ for 48 hours, counting of all typical colonies using colony counter was performed. For confirmation, five typical colonies were selected and transferred to brain heart infusion broth tubes (BHIB) (Oxoid CM1135) for subsequent culture and preservation. Presumptive colonies were transferred and subcultured on Mannitol Salt Agar (Oxoid CM0085) and then incubated for $24 \mathrm{hrs}$ at $37^{\circ} \mathrm{C}$. Gram stain, catalase, mannitol fermentation, DNAs and coagulase tests were applied on suspected colonies to identify coagulase $S$. aureus (18). In addition, VITEK 2-compact was used to identify and differentiate staphylococci species (BioMérieux, Rev 03, 2004).

\section{Screening for MRSA}

Screening of All S. aureus isolates for their methicillin resistance was done by the standard disc diffusion procedure described by Clinical and Laboratory Standards Institute (19) using cefoxitin $(30 \mu \mathrm{g})$.

\section{DNA Extraction}

Staphylococcus aureus isolates were grown in BHIB at $37^{\circ} \mathrm{C}$ for 18 hours. The cells were harvested by centrifugation at $8000 \mathrm{rpm}$ for 20 minutes at $4^{\circ} \mathrm{C}$ and washed twice by phosphatebuffered saline. The pellet was suspended in 1 $\mathrm{ml}$ of $10 \mathrm{mMTris}-\mathrm{HCl}(\mathrm{pH} 8)$ containing lysozyme $(2.5 \mathrm{mg} / \mathrm{ml})$ and incubate at $37^{\circ} \mathrm{C}$ for 2 hours. Genomic DNA was extracted using QIAamp DNA Mini Kit (QIAGEN) according to the instructions from manufacturer.

\section{DNA amplification by Polymerase Chain Reaction (PCR):}

\section{Detection of Staphylococcus 16S rRNA}

PCR was used for detection of Staphylococcus $16 \mathrm{~S}$ rRNA using primers in (Table 1), according to (20). The PCR was performed in a 25 ul volume, where $2 \mathrm{ul}$ of the extracted DNA (100-ng) was added to $12.5 \mathrm{ul}$ of oasig TM2X 
qPCR Master mix , 1 ul $(0.5 \mathrm{mM}$ concentration) of each primer set and 8.5 ul PCR grade H2O.PCR amplifications were performed in a MyGenie 32 Thermal Block (BIONEER as follows: Initial denaturation at $94^{\circ} \mathrm{C}$ for 5 min followed by 35 cycles of $94^{\circ} \mathrm{C}$ for $1 \mathrm{~min}, 57^{\circ} \mathrm{C}$ for $1 \mathrm{~min}$, and $72^{\circ} \mathrm{C}$ for $2 \mathrm{~min}$ and ended with final extension for $10 \mathrm{~min}$ at $72^{\circ} \mathrm{C}$ and finally maintained at $4^{\circ} \mathrm{C}$.

\section{Detection of mecA-gene}

The polymerase chain reaction (PCR) was used for detection of mecA-gene in antibiotic resistance strains using primers in (Table 1), according to (21). In a final volume of $50 \mathrm{ul}$, three $\mathrm{ul}$ of DNA template was added to $25 \mathrm{ul}$ of oasig TM2X qPCR Mastermix; 1 ul (0.25 mM concentration) of each primer set and $20 \mathrm{ul} \mathrm{PCR}$ grade H2O. DNA amplifications were carried out in a MyGenie 32 Thermal Block (BIONEER as follows: Initial denaturation at $94^{\circ} \mathrm{C}$ for $5 \mathrm{~min}$ followed by 36 cycles of denaturation of $94^{\circ} \mathrm{C}$ for $30 \mathrm{~s}$, annealing at $55^{\circ} \mathrm{C}$ for $30 \mathrm{~s}$, and extension at $72^{\circ} \mathrm{C}$ for $1 \mathrm{~min}$ with a final extension at $72^{\circ} \mathrm{C}$ for 5 min. Strain MF01 (GenBank, KY647024.1) was used as a positive control for mecA gene.Ten microliters of PCR products (16S rRNA and mecA-genes) was analyzed by $1 \%$ agarose gel electrophoresis. A 100 bp molecular weight DNA ladder (Gel Pilot Plus, QIAGEN) was used for the validation of length of the amplified products.

\section{Antimicrobial susceptibility}

All isolates were tested using 10 antimicrobial agents: Penicillin G (10U), ampicillin (10 $\mu \mathrm{g})$, tetracycline $(30 \mu \mathrm{g})$, amoxicillin-clavulanic acid $(20 / 10 \mu \mathrm{g})$, ciprofloxacin $(5 \mu \mathrm{g})$, cefoxitin $(30 \mu \mathrm{g})$, trimethoprim/sulfamethoxazole $(1.25 / 23.75 \mu \mathrm{g})$, erythromycin $(15 \mu \mathrm{g})$, clindamycin $(2 \mu \mathrm{g})$, gentamicin $(10 \mu \mathrm{g})$, Antimicrobial sensitivity was monitored with the standard disk diffusion assay .The zone of inhibition was interpreted according to CLSI guidelines (19). S. aureus ATCC 25923 was used as reference strain.

\section{Results}

Primers for both staphylococcus 16S rRNA and mecA-gene were tabulated in table (1). Identification of $S$. aureus was done by DNA expression of gene specific $16 \mathrm{~S}$ rRNA gene (figure 1).

Figure (2) clarified that, S. aureus was present in 20 out of the 187 samples $(10.7 \%)$. Of the $20 \mathrm{~S}$. aureus isolates, three (15\%) were found to be MRSA, therefore, Figure 2 shows the prevalence of MRSA strains among total samples was only three (3/187) (1.6\%).

Identification of MRSA was done by DNA expression of gene specific mec-A gene (figure $3)$.

Table (2) showed different patterns of Antimicrobial susceptibility of $S$. aureus isolates. $35 \%$ were resistant to $\beta$-lactam, $50 \%$ were resistant to penicillin, $65 \%$ were sensitive to ciprofloxacin, $90 \%$ were sensitive to Erythromycin and Clindamycin, $85 \%$ were sensitive to Cefoxitin, $80 \%$ sensitive to Gentamicin, $60 \%$ were resistant to Penicillin G, 75\% were sensitive to Trimethoprim and finally $75 \%$ were sensitive to tetracycline.

Figure (4) declared the percentages of S. aureus resistant strains among the identified isolates using the disk diffusion method according to Clinical and Laboratory Standards Institute guidelines. Results showed a higher resistant level for both penicillin and Ampicillin (60\% and $50 \%$, respectively). As shown in table (3), only two isolates (10\%) out of all analyzed strains exhibited single resistance to penicillin. MRSA isolates presented antimicrobial multi resistance. 
Table 1: Primers for both Staphylococcus 16S rRNA and mecA-gene

\begin{tabular}{llll}
\hline \multicolumn{1}{c}{ DNA target } & \multicolumn{1}{c}{ Primer pair } & Size (bp) & Reference \\
\hline $\begin{array}{l}\text { Staphylococ- } \\
\text { cus }\end{array}$ & 5'GTT ATT AGG GAA GAA CAT ATG TG-3' & 750 & Jaffe et al., \\
rRNA & 5'CCA CCT TCC TCC GGT TTG TCA CC-3' & & 2000 \\
mecA-gene & 5' AAAATCGATGGTAAAGGTTGGC-3' & 530 & Murakami \\
& 5' AG TTCTGCAGTACCGGATTTGC-3' & & et al., 1991 \\
\hline
\end{tabular}

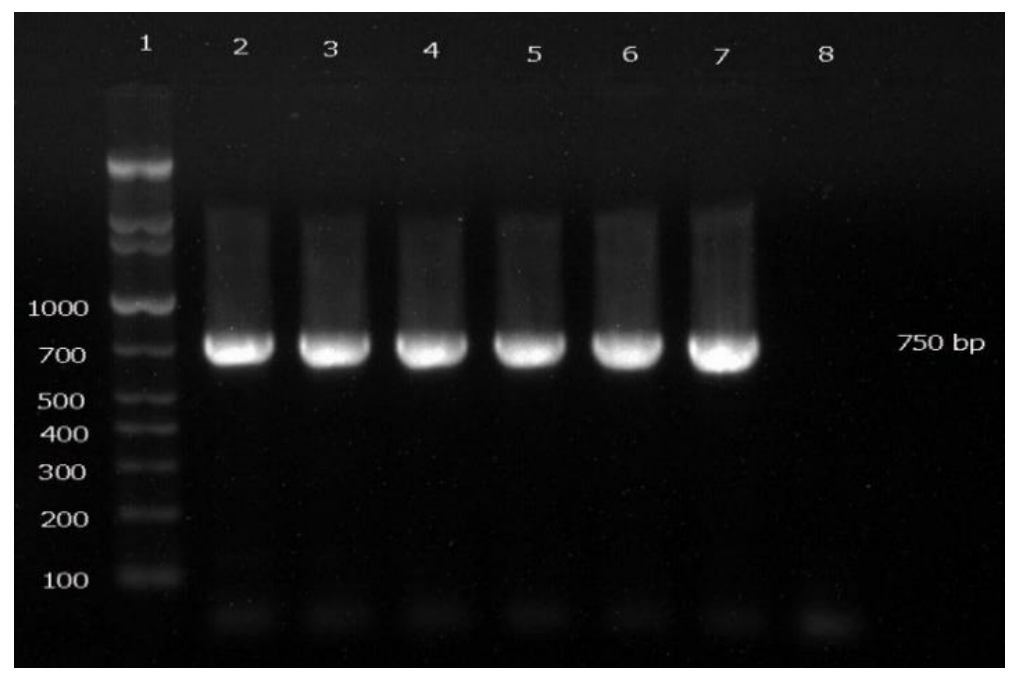

Figure 1: Agarose gel electrophoresis of amplified 750-bp DNA fragment. Lanes: 1 DNA ladder molecular weight marker (GelPilot), 2-6 staphylococcus isolates, 7 ATCC 12600

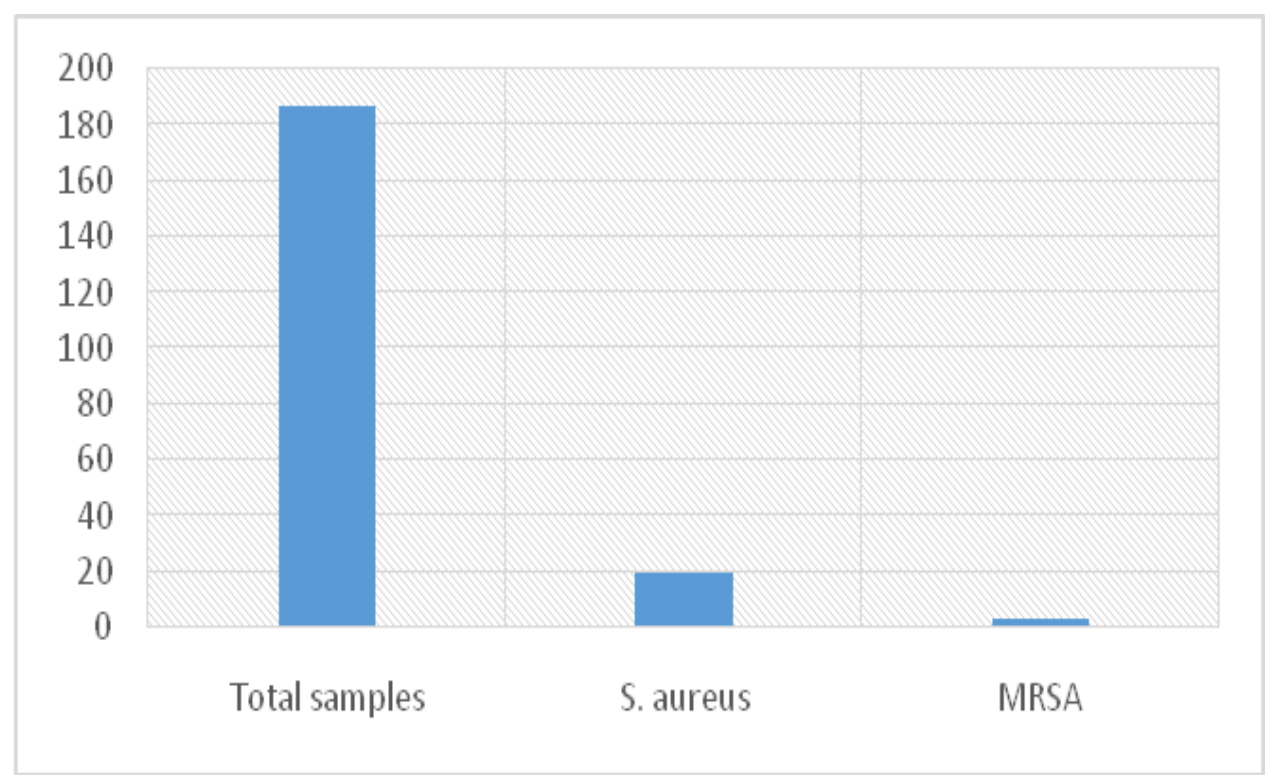

Figure 2: Prevalence (\%) of S. aureus and MRSA in camel meat samples 


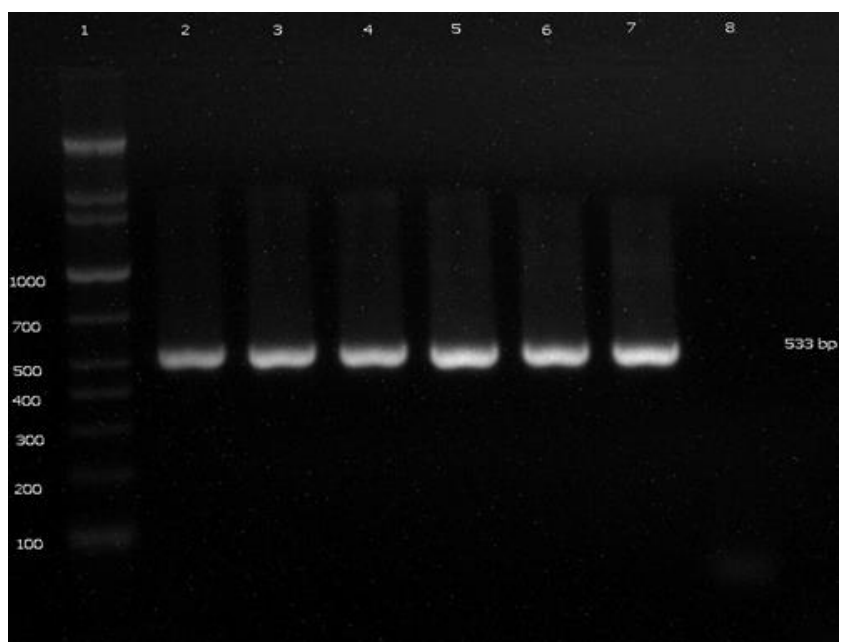

Figure 3: Agarose gel electrophoresis of amplified 533-bp DNA fragment. Lanes: 1 DNA ladder molecular weight marker (GelPilot), 2-6 MRSA isolates, 7 Strain MF01, 8 Negative control.

Table 2: Antimicrobial susceptibility of $S$. aureus isolates $(\mathrm{n}=20)$ :

\begin{tabular}{ccccc}
\hline \% $\mathbf{S}$ & \% I & \% $\mathbf{R}$ & Antibiotic class & Antimicrobial agent \\
\hline 65 & 0 & 35 & $\beta$-lactam+Inhibitors & Amoxicillin/Clavulanic acid (AMC) \\
50 & 0 & 50 & Penicillins & Ampicillin (AMP) \\
65 & 5 & 30 & Quinolones & Ciprofloxacin (CIP) \\
90 & 0 & 10 & Lincosamides & Clindamycin (CLI) \\
90 & 0 & 10 & Macrolides & Erythromycin (ERY) \\
85 & 0 & 15 & Cephems & Cefoxitin (FOX) \\
80 & 0 & 20 & Aminoglycosides & Gentamicin (GEN) \\
40 & 0 & 60 & Penicillins & Penicillin G (PEN) \\
75 & 0 & 25 & Folate pathway inhibitors & Trimethoprim/Sulfamethoxazole (SXT) \\
75 & 0 & 25 & Tetracyclines & Tetracycline (TCY) \\
\hline
\end{tabular}

$\mathrm{R}=$ Resistant, $\mathrm{T}=$ Intermediate, $\mathrm{S}=$ Sensitive

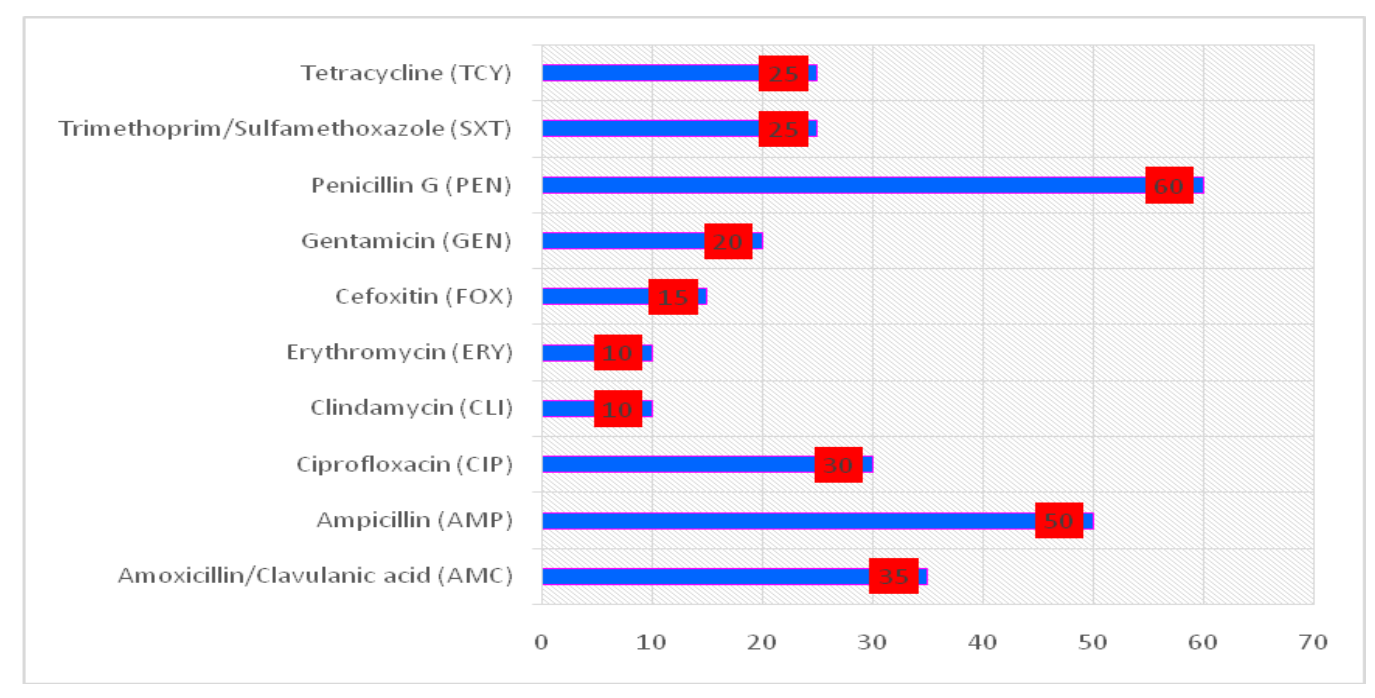

Figure 4: Percentages of $S$. aureus resistant strains among the identified isolates using the disk diffusion method according to Clinical and Laboratory Standards Institute guidelines 
Table 3: Antibiotic resistance profile (number of $\mathrm{S}$. aureus isolates=20)

\begin{tabular}{|c|c|c|c|c|c|c|c|c|c|c|c|}
\hline$\%$ & $\begin{array}{l}\text { N. of } \\
\text { iso- }\end{array}$ & \multicolumn{10}{|c|}{ Resistance profile } \\
\hline 40 & 8 & & & & & & & & & & \\
\hline 10 & 2 & PEN & & & & & & & & & I \\
\hline 5 & 1 & PEN & AMP & & GEN & & & & & & II \\
\hline 5 & 1 & PEN & AMP & CIP & & & & & & & III \\
\hline 5 & 1 & PEN & AMP & CIP & GEN & TCY & & & & & IV \\
\hline 10 & 2 & PEN & AMC & AMP & & & & & & & V \\
\hline 5 & 1 & PEN & AMC & AMP & CIP & SXT & & & & & VI \\
\hline 5 & 1 & PEN & AMC & AMP & CIP & CLI & GEN & SXT & TCY & & VII \\
\hline 5 & 1 & FOX & PEN & $\mathrm{AMC}$ & AMP & CIP & GEN & SXT & TCY & & VIII \\
\hline 5 & 1 & FOX & PEN & $\mathrm{AMC}$ & AMP & ERY & CIP & SXT & TCY & & IX \\
\hline 5 & 1 & FOX & PEN & AMC & AMP & ERY & CIP & CLI & SXT & TCY & $X$ \\
\hline
\end{tabular}

\section{Discussion}

As a major meat species marketed in Saudi Arabia, camel meat was used for determination of the prevalence of $S$. aureus\& MRSA and antimicrobial susceptibility profile of isolates. In a survey conducted for 5 months, 187 raw camel meat samples (retailed in Al-Hasa, Saudi Arabia) were analyzed. Identification of $S$. $a u$ reus was done by DNA expression of gene specific $16 \mathrm{~S}$ rRNA (figure 1).

Figure (2) clarifies that, S. aureus was present in 20 out of the 187 samples $(10.7 \%)$. The prevalence of $S$. aureus in different foodstuffs and meats varied in the previous studies. They were reported $20.5 \%$ S. aureus from beef at USA (22).

MRSA has been already isolated and identified from retail meat worldwide, and the possible human transmission existed (23-26 and 22). The reported prevalence varied which indicated that contamination by MRSA in different types of meat varied in the different localities. Of the $20 \mathrm{~S}$. aureus isolates, three $(15 \%)$ were found to be MRSA, therefore, Figure 2 shows the prevalence of MRSA strains among total samples was only three (3/187) $(1.6 \%)$ and this result is very low in comparison with that obtained by (16) who found that the prevalence of MRSA in camel meat retailed in Riyadh was (20\%) while the prevalence of MSSA was $(28 \%)$. This difference may be due to variations in hygienic levels, preparation and handling of meat. While our result was nearly similar to (22) and (27) who reported that $1.3 \%$ and $1.2 \%$, respectively were positive for MRSA from meat retailed in USA.

Meat play a significant role in transmission of antimicrobial resistance from livestock and food animals to human being, and antibiotic resistance usually has a great concern in hospital infection (nosocomial infections). Antimicrobial resistance may transfer via 3 ways: Through antimicrobial residues in food and meat, or consumption of resistant parts of original food microflora and transfer resistance to pathogenic microorganisms (28-31).

The antimicrobial resistance was higher for Penicillin G and Ampicillin (60 and 50\%, respectively). In addition, $15 \%$ of tested $S$. aureus strains were methicillin-resistant while $85 \%$ were sensitive to cefoxitin (table 2). Another study showed antibiogram sensitivity differences in S. aureus isolated from food (7).

It was clear that MRSA isolates were resistant to all antimicrobials used.

Figure 4 showed a higher resistant level for both penicillin and Ampicillin and this result is similar to that stated by (32) in chicken giblets. Only two isolates (10\%) out of all analyzed strains exhibited single resistance to penicillin. MRSA isolates presented antimicrobial multi resistance (7 and 32); similar result was found in our study (table 3 ). 


\section{Conclusion}

From the above, it could be concluded that $20 \mathrm{~S}$. aureus positive isolates were identified out of 187 camel meat samples $(10.7 \%$ prevalence). Three were resistant to methicillin (1.6 $\%$ prevalence), $35 \%$ of $S$. aureus isolates were resistant to $\beta$-lactam antibiotic. MRSA isolates were resistant to all antimicrobials tested, and $15 \%$ of tested $S$. aureus strains were methicillin-resistant. Our results indicated low MRSA prevalence in camel meat, which pointed to the limited risk of transmission via meat. However, attention should be paid to the safety along food chain.

\section{Conflict of interest}

The authors declare that they have no conflict of interest.

\section{Acknowledgment}

The authors thank the Deanship of Scientific Research in King Faisal University, Saudi Arabia, for their support of this study. Many thanks is due to Prof. Dr. Mohammed M. Abdel Mohsen for his valuable reviewing and proof editing.

\section{References}

1. Atanassova V, Meindl A, Ring C. Prevalence of Staphylococcus aureus and staphylococcal enterotoxins in raw pork and uncooked smoked ham: a comparison of classical culturing detection and RFLP-PCR. Int J Food Microbiol 2001; 68:105-13.

2. Jett M, Ionin B, Das R, Neill R. The staphylococcal enterotoxins. In: Sussman M, editor. Molecular medical microbiology. San Diego, CA, USA: Academic Press2001; 1089:116.

3. Seguin JC, Walker RD, Caron JP, Kloos WE, George CG, Hollis RJ, Jones RN, Pfaller MA. Methicillin-resistant Staphylococcus aureus outbreak in a veterinary teaching hospital: potential human-to-animal transmission. Journal of Clinical Microbiology 1999; 37: 1459-63.

4. Petinaki E, Spiliopoulou I. Methicillin-resistant Staphylococcus aureus among companion and food chain animals: impact of human contacts. Clin Microbiol Infect 2012; 18(7):626-34.

5. Greeson K, Suliman GM, Sami A, Alowaimer A, Koohmaraie M. Frequency of antibiotic resistant Salmonella, Escherichia coli, Enterococcus and
Staphylococcus aureus in meat in Saudi Arabia. Afr. J. Microbiol. Res 2013; 7: 309-16.

6. EFSA (European Food Safety Authority). Scientific opinion of the panel on biological hazards on a request from the European Commission on Assessment of the Public Health Significance of methicillin resistant Staphylococcus aureus (MRSA) in animals and foods. EFSA J. 993; 1-73.

7. Pesavento G, Ducci B, Comodo N, Lo Nostro A. Antimicrobial resistance profile of Staphylococcus aureus isolated from raw meat: A research for methicillin resistant Staphylococcus aureus (MRSA). Food Control 2007; 18: 196-200.

8. Traversa GR, Gariano S, Gallina DM, Bianchi, Orusa R, Domenis L, Cavallerio P, Fossati L, Serra R, Decastelli L. Methicillin resistance in Staphylococcus aureus strains isolated from food and wild animal carcasses in Italy. Food Microbiol. 2015; 52: 154-8.

9. Austin TW1, Austin MA, McAlear DE, Coleman BT, Osoba AO, Thaqafi AO, Lamfon MA. MRSA prevalence in a teaching hospital in Western Saudi Arabia. Saudi Med J 2003; 24(12):1313-6.

10. El Amin NM, Faidah HS. Methicillin-resistant $S$. aureus in the western region of Saudi Arabia: prevalence and antibiotic susceptibility pattern. Ann Saudi Med. 2012; 32(5):513-6.

11. Iyer AP, Baghallab I, Albaik M, Kumosani T. Nosocomial Infections in Saudi Arabia Caused by Methicillin Resistance Staphylococcus aureus (MRSA). Clin Microbial 2014; 3: 146.

12. Dagunton N, Salman K, Al-Saif S, Balkhy H. MRSA outbreak at a neonatal ICU in Saudi Arabia. Journal of Infection and Public Health 2015; 8 (4), 402-3.

13. Al Yousef SA, Taha EM. Methicillin-Resistant Staphylococcus aureus in Saudi Arabia: Genotypes distribution review. Saudi J Med Med Sci 2016 ; 4:2-8

14. El-Deeb W, Fayez M, Elmoslemany A, Kandeel M, Zidan K. Methicillin resistant Staphylococcus aureus among goat farms in Eastern province, Saudi Arabia: Prevalence and risk factors. Prev Vet Med. 2018; 156:84-0.

15. Quddoumi SS, Bdour SM, Mahasneh AM. Isolation and characterization of methicillin-resistant Staphylococcus aureus from livestock and poultry meat. Annals of Microbiology 2006; 56 (2): 155-61.

16. Raji MA, Garaween G, Ehricht R, Monecke S, Shibl AM and Senok A. Genetic Characterization of Staphylococcus aureus Isolated from Retail Meat in Riyadh, Saudi Arabia. Front. Microbiol. 2016; 7: 911. 
17. American Public Health Association (APHA). Compendium of methods for the microbiological examination of food ( $4^{\text {th }}$ ed.) 2001. Washington, DC: Author.

18. Quinn PJ, Markey BK, Leonard FC, Fitzpatrick ES, Fanning S, Hartigan P. Veterinary microbiology and microbial disease ( $2^{\text {nd }}$ ed.) 2011; Oxford: Wiley-Blackwell.

19. Clinical and Laboratory Standards Institute (CLSI). Wayna, pa: Performance Standards for Antimicrobial Susceptibility Testing; Twenty-Fourth Informational Supplement 2014. Approved M100S24.

20. Jaffe RI, Lane JD, Albury SV, Niemeyer DM. Rapid extraction from and direct identification in clinical samples of methicillin-resistant staphylococci using the PCR. J Clin Microbiol. 2000; 38:3407-12.

21. Murakami K, Minamide W, Wada K, Nakamura E, Teraoka H. Identification of methicillin-resistant strains of staphylococci by polymerase chain reaction. J Clin Microbiol 1991; 29: 2240-4.

22. Bhargava K, Wang X, Donabedian S, Zervos M, da Rocha L, Zhang Y. Methicillin-resistant Staphylococcus aureus in retail meat, Detroit, Michigan,USA [letter].Emerg Infect Dis. 2011;1-4.

23. $\mathrm{Pu} \mathrm{S}$, Han F, Ge B. Isolation and characterization of methicillin-resistant Staphylococcus aureus strains from Louisiana retail meats. Appl Environ Microbiol. 2009; 75:265-7.

24. Weese JS, Avery BP, Reid-Smith RJ. Detection and quantification of methicillin-resistant Staphylococcus aureus (MRSA) clones in retail meat products. Lett ApplMicrobiol. 2010; 51:33842.
25. Lim SK, Nam HM, Park HJ, Lee HS, Choi MJ, Jung SC. Prevalence and characterization ofmethicillin-resistant Staphylococcus aureus in raw meat in Korea. J Microbiol Biotechnol. 2010; 20:775-8.

26. de Boer E, Zwartkruis-Nahuis JT, Wit B, Huijsdens XW, de Neeling AJ, Bosch T. Prevalence of methicillin-resistant Staphylococcus aureus in meat. Int J Food Microbiol. 2009; 134:52-6.

27. Hansona BM, Dresslera AE, Harpera AL, Scheibel RP, Wardyna SE, L.K. Roberts LK, Kroegera JS, Smitha TC. Prevalence of Staphylococcus aureus and methicillin-resistant Staphylococcus aureus (MRSA) on retail meat in Iowa. Journal of Infection and Public Health 2011; (4): 16974.

28. Kruse H, Sorum H. Transfer of multiple drug resistance plasmids between bacteria of diverse origins in natural microenvironments. Applied and Environmental Microbiology 1994; 60(11): 4015-21.

29. Klein G. Food as a potential vector for antibiotic resistance. Berline Munch Tierarztl Wochenschr 1999; 112: 365-9.

30. Teuber M. Spread of antibiotic resistance with food-borne pathogens. Cellular and Molecular Life Sci. 1999; 56: 755-63.

31. Mayrhofer S, Paulsen P, Smulders FJ, Hilbert F. Antimicrobial resistance profile of five major food-borne pathogens isolated from beef, pork and poultry. Int. J. Food Microbiol. 2004; 97: 23-9.

32. Darwish WS, Atia AS, Reda LM, Elhelaly AE, Thompson LA, Saad Eldin WF. Chicken giblets and wastewater samples as possible sources of methicillin-resistant Staphylococcus aureus: Prevalence, enterotoxin production, and antibiotic susceptibility. J Food Saf. 2018; 12:1-7. 